Transport Geography. Volume 36, April 2014, Pages $1-11$.

23. Khanal B. R. Tourism inter-industry linkages in the Lao PDR economy: An input-output analysis / B. R. Khanal, C. Gan, S. Becken // Tourism Economics. -2014. - 20 (1). - P. 171194.
24. Pratt S. Economic linkages and impacts across the Talc. / S. Pratt // Annals of Tourism Research. - 2011. - 38 (2). - P. 630-650.

25. The impacts of Australia's departure tax: Tourism versus the economy? / Forsyth P., Dwyer L., Spurr R., Pham T. // Tourism Management. 2014. - 40. - P. 126-136.

Експерт редакційної колегії к.е.н., доцент УкрДУЗТ Боровик Ю.Т.

УДК 656.2.003.1

\title{
СТРАТЕГІЯ УПРАВЛІННЯ РЕФОРМУВАННЯМ ЗАЛІЗНИЧНИМ ТРАНСПОРТОМ УКРАЇНИ
}

\author{
Бараи Ю.С., д.е.н., професор, \\ Чаркіна Т. Ю., к.е.н., доцент (ДНУЗТ)
}

\begin{abstract}
Авторами удосконалено метод побудови організачійних структур управління Департаментів (Главків), побудованих за продуктовим принцииом замість існуючого регіонального, завдяки використанню якого вдалося скоротити ланцюг команд, зменшити ієрархію управлінських рівнів, організувати нові функиіональні підприємства та знизити експлуатаційні витрати на перевезення.

Впровадження нової організаційної структури управління дозволяе оптимізувати діяльність департаменту на різних рівнях управління, скоротити чисельність прачівників та підвищити продуктивність прачі

Ключові слова: залізничний транспорт; організаційна структура управління; стратегія управління
\end{abstract}

\section{СТРАТЕГИЯ УПРАВЛЕНИЯ РЕФОРМИРОВАНИЕМ ЖЕЛЕЗНОДОРОЖНЫМ ТРАНСПОРТОМ УКРАИНЫ}

Бараш Ю. С., д.э.н., профессор, Чаркина Т. Ю., к.э.н., доцент (ДНУЖТ)

\begin{abstract}
Авторами усовершенствован метод построения организаиионных структур управления Департаментом (Главком), организованных по продуктовому приниипу вместо существующего регионального, с помощью которого удалось сократить иепь команд, уменьшить иерархию управленческих уровней, организовать новые функииональные предприятия и снизить эксплуатаиионные затраты на перевозки.

Внедрение новой организачионной структуры управления позволяет оптимизировать деятельность департамента на разных уровнях управления, сократить численность работников $u$ поднять производительность труда.
\end{abstract}

Ключевые слова: железнодорожный транспорт; организационная структура управления; стратегия управления 


\title{
MANAGEMENT STRATEGY OF UKRAINE RAILWAY REFORM
}

\author{
Barash Y.S., Doctor of Economic Sciences, professor \\ Charkina T.V., Candidate of Economic Sciences \\ (Dnipropetrovsk National University of Railway Transport)
}

Authors improved the method of constructing organizational structures of departments' management, which are built according to product principle of organizational structure instead of regional that exists now. The method allows reducing the chain of commands, administrative levels hierarchy, operating costs for transportation and organizing new functionality enterprises.

Implementation of a new organizational structure allows optimizing department activities at various levels of management, reducing the number of employees and increasing productivity.

Keywords: rail; organizational management structure; management strategy

Постановка проблеми та ії зв'язки 3 науковими чи практичними завданнями.

Ефективне функціонування залізничного транспорту пов'язане 3 удосконаленням його організаційної структури; оновленням основних фондів і рухомого складу; впровадженням новітніх технологій і високошвидкісного руху; наданням нових видів послуг i захопленням нових секторів транспортного ринку; збільшенням прибутковості перевезень вантажів і пасажирів та інтегруванням до європейської транспортної системи.

Нестача власних коштів та відсутність бюджетного фінансування, неможливість залучення недержавних інвестицій (до 2016 р.) призвели до небезпечного збільшення фізичного зносу та морального старіння основних фондів, втрати частки пасажирських та вантажних перевезень. Тому після листопаду 2016 року залізниці України було зареєстровано як Публічне акціонерне товариство «Укрзалізниця» (ПАТ «УЗ»).

Де-юре юридично була створена нова організаційна структура управління залізничними перевезеннями вантажів i пасажирів в Україні, але де-факто структурна реформа на залізничному транспорті лише розпочалася.

Для вирішення вказаної проблеми необхідно розробити стратегію управління діяльністю ПАТ «УЗ» на певний період часу.

Дана стаття написана по матеріалах наукових звітів, які виконувала Галузева науково-дослідна лабораторія «Економіка та управління транспортом» Дніпропетровського національного університету залізничного транспорту імені академіка В. Лазаряна за договорами:

«Дослідження перспективної моделі управління залізничним транспортом у ринкових умовах 3 визначенням оптимальної організаційно-правової форми суб'єкта господарювання», номер державної реєстрації $0103 \mathrm{U} 007280$.

«Розробка техніко-економічного

обгрунтування (TEO) та програми реформування пасажирського господарства», номер державної реєстрації 0103U007781.

«Розробка науково обгрунтованої програми розвитку пасажирського господарства в умовах ринкових перетворень», номер державної реєстрації 0104U008415.

публікацій.

Дослідженням даної проблеми в різні періоди займалися провідних вчені та спеціалісти у галузі реформування залізничного транспорту, зокрема: В. Л. Дикань [5], В. П. Гудкова [4, 14], Ю. Ф. Кулаєв, М. В. Макаренко, А. М. Новікова, Ю. Є. Пащенко, Е. А. Петренко [8-10], О. М. Пшінько [11], Ю. М. Цветов, Г.Д. Ейтутіс [7], О. М. Гненний, Н. Б. Малахова, Ю. В. Булгакова [3], Л. В. Марценюк [11], Чайкіна Т. Ю. [12], Т. А. Мукмінова, Г. М. Кірпа, А. Д. Лашко, В. І. Сіраков, Ю. М. Федюшин, та інших.

Доктор Ж.-П. Естіваль - президент Європейської асоціації залізничників зробив аналіз і виділив три види структурних моделей реформування залізничного транспорту, які прийняті серед країн-кандидатів у члени ЄС [6].

«...Модель розділення (інституційне розділення операторів інфраструктури i підприємств, що здійснюють залізничні перевезення). Піонером такої моделі є Швеція. Кожну сферу діяльності там здійснює самостійна юридична особа 3 відокремленим балансом, звітністю і відповідальністю за результати діяльності. Цю модель 3 відповідною національною адаптацією використано в 
скандинавських країнах, Великій Британії, Іспанії, Португалії, Франції та Голландії.

Інтеграційна модель. Сфери діяльності (крім управління інфраструктурою та надання перевізних послуг) незалежні одна від одної 3 позиції управління і мають окремі рахунки та окремий баланс. Але відповідні організаційні структури не $€$ самостійними юридичними особами. Інтегроване підприємство в цьому випадку $є$ єдиною юридичною особою. На сьогодні ця модель працює в Бельгії, Росії та Люксембурзі. До 1997 р. вона діяла у Франції. Для унеможливлення будь-якої дискримінації цим підприємствам необхідно розподіляти надану перевізну оплату та збори за використання залізничної лінії відповідно до директиви 2001/12/СС.

Холдингова модель (трансформація в холдинг) є результатом поєднання двох перших моделей. У цьому випадку юридично незалежні суб'єкти діяльності мають свободу дій, але їхні стратегіï визначаються організаційною структурою управління холдингу. Цей шлях пройшла Німеччина, а згодом сюди приєднались Італія, Австрія та Греція.

Деякі спеціалісти вважають цю модель останньою стадією удосконалення інтеграційної моделі. Інші вбачають у ній початок нового розвитку, який в надалі має прийти до моделі розділення.

Таким чином країни-кандидати на членство в ЄC мають три можливості реструктуризації залізниць, аби виконати вимоги ЄC. Навряд чи можливий четвертий шлях. Хоча у будь-якому випадку не виключаються специфічні національні адаптації залізниць до організаційноправової структури суб'єкта діяльності...».

Виділення невирішених частин загальної проблеми, яким присвячена стаття.

Україна зробила вибір та почила реалізовувати інтеграційну модель управління залізничним транспортом. Цю модель в Україні прийнято називати вертикально-інтегрована, яка передбачає розподіл залізничної діяльності на верхньому рівні по окремих департаментах. Але на другому та третьому рівні управління остаточно не визначена організаційна структура дирекцій, регіональних філій та відокремлених структурних підрозділів. завдання.

Формування цілей статті (постановка

Основна мета статті - розробити стратегію управління ПАТ «УЗ» - узагальнену модель дій спрямованих на досягнення мети через нову організаційну структуру управління залізничним транспортом країни, що дозволить ій ефективно функціонувати в умовах сучасного ринку.

Для вирішення поставлених завдань використовувалися методи: прийняття рішень, стратегічного планування та системний підхід для проведення наукових досліджень стосовно визначення оптимальної моделі управління залізничним транспортом; організаційнорозпорядчий - для побудови організаційних структур управління залізничним транспортом; порівняльного економічного аналізу - для прогнозування перспективних показників роботи нових транспортних структур за різними моделями.

дослідження.

$$
\text { Виклад основного матеріалу }
$$

Коли у країні відбувається процес занепаду економіки, пов'язаний 3 революційними, військовими подіями, розривом економічних зв'язків, перерозподілом ринку транспортних послуг тощо, на залізничному транспорті також настає криза, і кожна країна шукає свій вихід з ситуації, що склалася. $С$ два шляхи виходу 3 кризи, кожен 3 яких має безліч варіантів (рис. 1).

«Для України, де останніми роками на фоні критичного зношення об'єктів інфраструктури та особливо рухомого складу відбувалося швидке зростання витрат залізничного транспорту, питання пошуку шляхів підвищення ефективності роботи підприємств залізничної галузі та посилення їх конкурентоспроможності були й залишаються надзвичайно актуальними.

Як відомо, світ не винайшов більш дієвого способу підвищення ефективності, ніж розвиток конкуренції, тому перебудова системи управління залізничним транспортом на ринкових засадах $є$ незворотною перспективою i для українських залізниць. У процесі реформ залізничний транспорт має бути звільнений від непрофільної діяльності, безпосередньо не пов'язаної 3 перевезеннями, 3 подальшим розділенням потенційно конкурентних та монопольних видів діяльності та перебудовою перевізної діяльності на ринкових засадах. Такою $\epsilon$ перспектива. Проте поки ще багато питань залишаються без відповіді, і головне з них - чи готове сьогодні українське суспільство, українська економіка та українські залізниці до повномасштабного розвитку ринкових відносин у 
галузі. Адже кожна реформа має свою ціну, так само як і певні ризики» [13, с. 7-8].

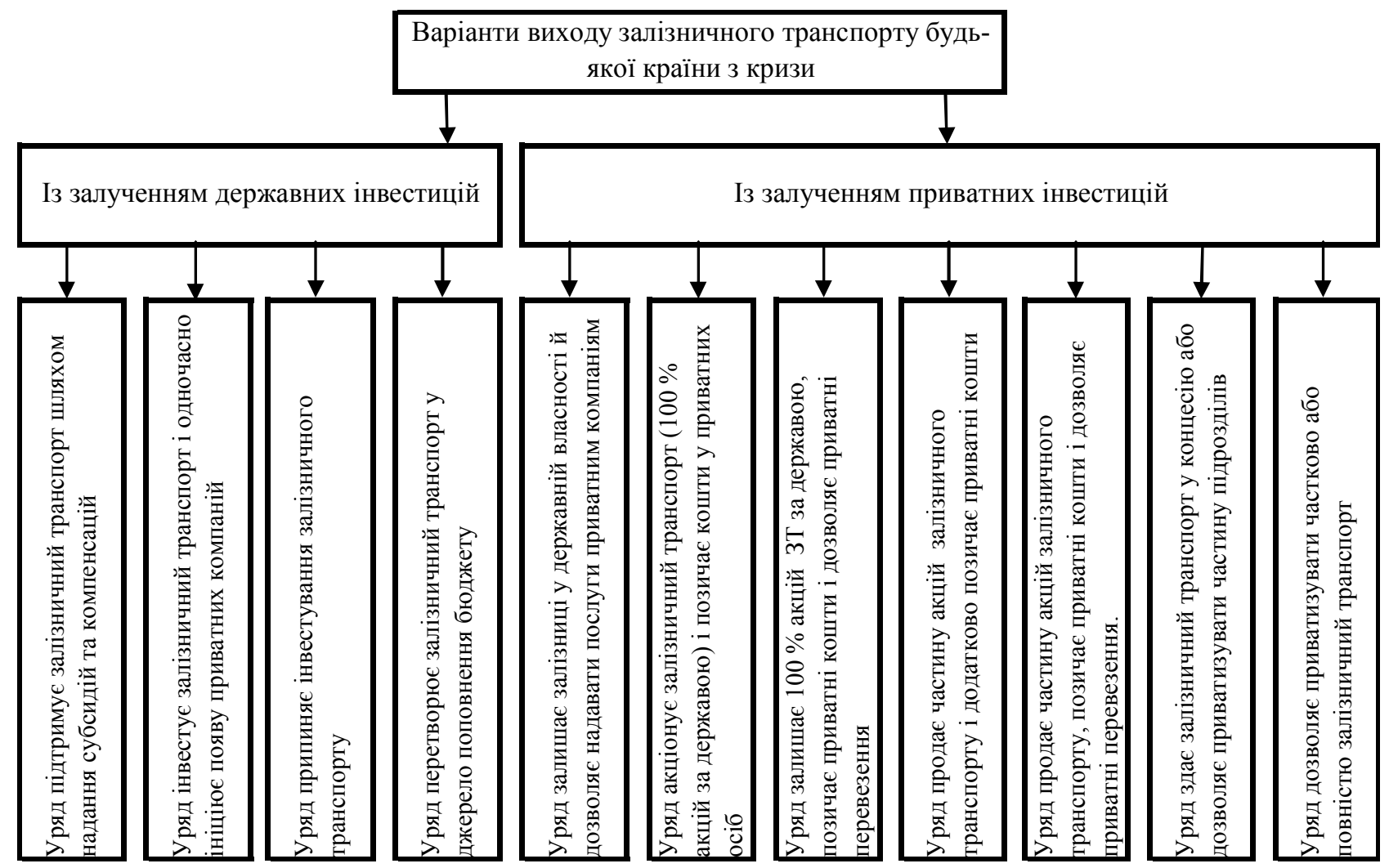

Рис. 1. Варіанти виходу залізничного транспорту з кризи в різних країнах світу

Проведений аналіз показав, що залізничний транспорт країни в основному працює стабільно і в цілому задовольняє зростаючі потреби суб'єктів підприємницької діяльності у вантажних перевезеннях та попит на пасажирські перевезення. Водночас висока вартість залізничних перевезень, яка значною мірою зумовлюється незадовільним станом інфраструктури та рухомого складу (а отже, потребує підвищених витрат на поточне утримання та ремонт), $\epsilon$ досить вагомою складовою витрат як для багатьох українських підприємств, так і для малозабезпечених верств населення [13, с. 259-261].

Стратегічна мета реформування залізничного транспорту полягає у сприянні економічному зростанню та підвищенню добробуту населення через забезпечення доступу до безпечних, надійних, високоякісних транспортних послуг за прийнятною ціною.

Задачі, що стоять перед залізничною галуззю:

- $\quad$ прискорення потоків пасажирів та товарів, зниження транспортних витрат в економіці та підвищення доступності транспортних послуг для населення;
- $\quad$ підвищення

конкурентоспроможності залізничної системи та більш повна реалізація транзитного потенціалу;

- підвищення безпеки та стабільності залізничних перевезень;

- покращення інвестиційного клімату та розвиток ринкових відносин» $[13$, с. 261].

Принциповими

реформування є:

- $\quad$ збереження єдиної державної інфраструктури залізниць;

- збереження державного регулювання i контролю за діяльністю залізничного транспорту;

- забезпечення

керованості, безперебійності, стабільності функціонування залізничного транспорту та безпеки руху поїздів;

- безумовне виконання перевезень для державних потреб;

- $\quad$ неможливість

допущення суттєвого відставання розвитку українських залізниць від залізниць країн Євросоюзу та Росії, які сьогодні знаходяться на різних стадіях процесу реформування, але при цьому суттєво випереджають Україну; 
$\bullet$

гармонізація

національного

законодавства 3 транспортним законодавством Євросоюзу;

реформування

українських

залізниць на основі європейського досвіду 3 урахуванням національних особливостей країни;

- поступовість (поетапність) процесу реформування, забезпечення постійного аналізу та контролю виконання заходів та корегування їх змісту з метою мінімізації ризику втрати безперебійності та безпеки роботи залізничного транспорту;

- забезпечення

безпечного функціонування залізничного транспорту та зниження його впливу на навколишнє природне середовище;

працівників;

- збереження соціального захисту

- збереження у складі суб'єкта господарювання об’єктів соціальної сфери, що сприяють створенню умов для безпеки руху поїздів та охорони праці.

Нижче подано як приклад побудова організаційної структури управління Департаменту пасажирських перевезень далекого сполучення, діяльність якого за технологічним принципом доцільно поділити на шість груп:

- $\quad$ вокзали позакласні та 1-го, 2-го та 3го класів, які надають пасажирам послуги, що пов'язані 3 продажем залізничних квитків, очікуванням прибуття та відправлення поїздів, оформленням багажу, а також санітарні, готельні та інші послуги;

- ОДБ та квиткові каси для оперативного продажу залізничних квитків на усі види пасажирських поїздів;

- компанії-оператори для перевезення пасажирів та надання їм усіх видів послуг під час подорожі;

- пасажирські вагонні депо для забезпечення планових та капітальновідновлювальних ремонтів вагонів;

- бази обслуговування та пральні комплекси для забезпечення пасажирів постільними речами, білизною та необхідним інвентарем;

- ремонтно-екіпірувальні депо та пункти для виконання поточних видів ремонту, санітарної обробки, мийки та екіпірування пасажирських поїздів.

Ці технологічно самостійні майнові комплекси об'єднуються за функціональним принципом у межах залізниці в регіональні підрозділи Департаменту пасажирських перевезень, які на різних етапах структурної реформи поступово змінюють свій статус від філії ПАТ «УЗ» до дочірніх підприємств та відкритих акціонерних товариств.

Після того як встановлено, до якого сектору повинні належати нові організаційні структури 3 перевезення пасажирів у далекому сполученні, і технологічно визначена оптимальна їх кількість, необхідно розробити послідовність ï реформування на кожному етапі структурної реформи. Перший етап пов'язаний з реєстрацією Публічного акціонерного товариства «Українська залізниця» та незначними змінами в існуючій структурі управління пасажирського господарства (рис. 2).

Головне пасажирське управління трансформується в Департамент пасажирського господарства, у якому окремо утворюється управління швидкісних перевезень, шість філій ПАТ «УЗ» на базі пасажирських служб залізниць та ще одна філія «Укрзалізничпассервіс» для прання білизни та обслуговування пасажирів у поїздах. Додатково до організаційної структури Департаменту пасажирського господарства включено вокзали другого та третього класів. Підготовлена до подальшого розподілу на другому етапі ремонтна база (окремо для експлуатації та ремонту).

значимість.

Наукова новизна та практична

Удосконалено метод побудови організаційних структур управління Департаментів (Главків), побудованих за продуктовим принципом замість існуючого регіонального, завдяки використанню якого вдалося скоротити ланцюг команд, зменшити ієрархію управлінських рівнів, організувати нові функціональні підприємства та знизити експлуатаційні витрати на перевезення.

Впровадження нової організаційної структури управління дозволяє оптимізувати діяльність департаменту на різних рівнях управління, скоротити чисельність працівників та підвищити продуктивність праці

Висновки даного дослідження i перспективи подальших робіт у цьому напрямку.

1. Пошук раціональної моделі ПАТ «УЗ» на усіх рівнях управління передбачає комплексне вирішення таких проблем:

1) відповідність моделі управління підприємством стану ринкових відносин та впливу чинників зовнішнього середовища; 
2) визначення стану ринкових відносин та перспектив їх розвитку;

3) визначення тенденції розвитку сучасного ринку в даній галузі;

4) визначення конкурентоспроможності підприємства та тенденцій його розвитку;

5) визначення антикризових заходів залежно від дії сил зовнішнього середовища.

2. У довгостроковій перспективі структурна реформа на залізничному транспорті повинна бути спрямована:

- на розвиток ринкових відносин;

- скорочення участі держави у

транспортній діяльності;

• розділення потенційно конкурентних та монопольних видів діяльності;

- скорочення монопольного сектору.

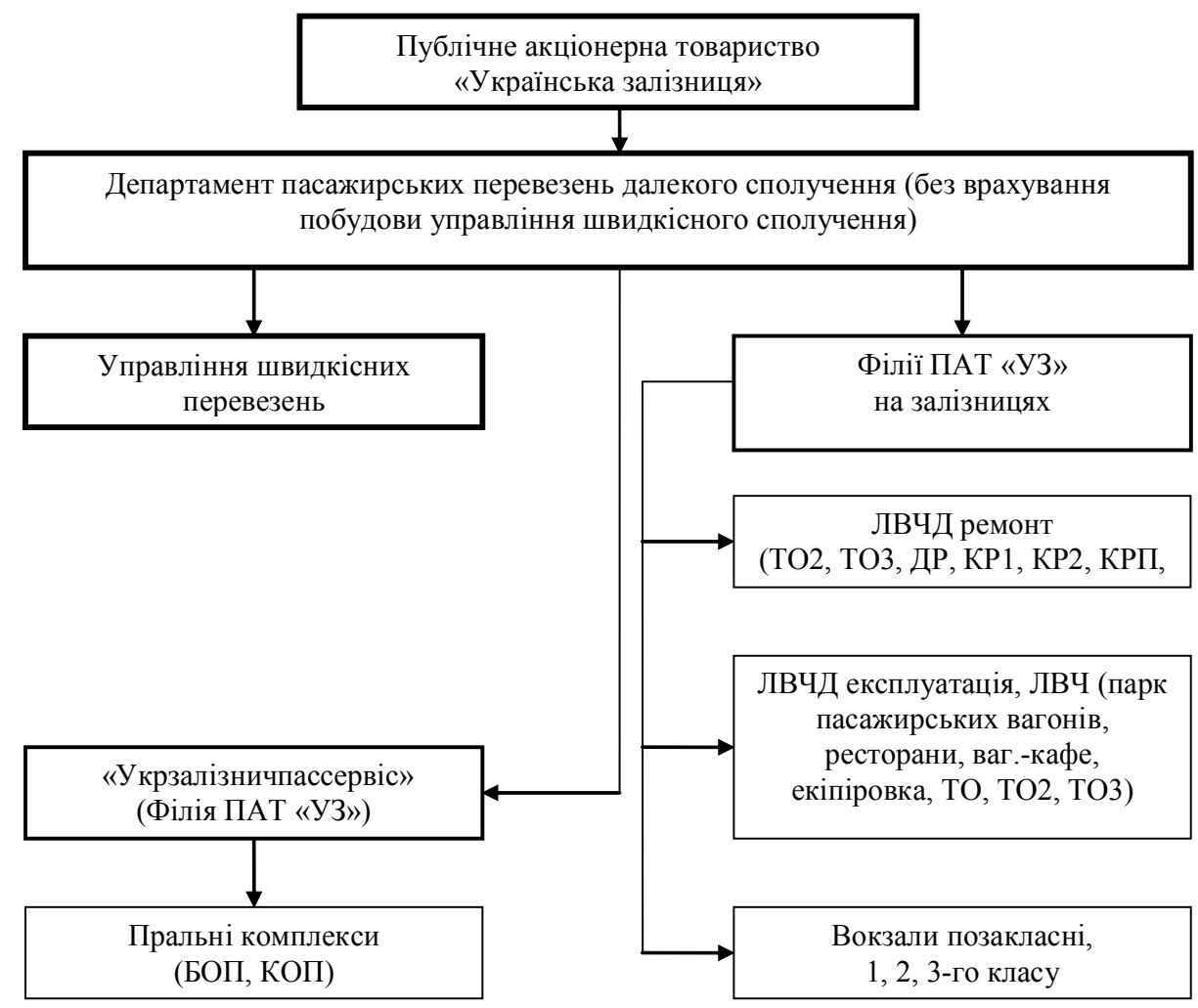

Рис. 2. Організаційна структура управління пасажирським господарством далекого сполучення на периому етапі структурної реформи

Стратегічна мета реформування залізничного транспорту полягає у сприянні економічному зростанню та підвищенню добробуту населення через забезпечення доступу до безпечних, надійних, високоякісних транспортних послуг за прийнятною ціною.

3. Для зниження вартості перевезень та залучення нових споживачів необхідно поділити залізничний транспорт на дві частини: природну монополію та конкурентне середовище. Природну монополію - інфраструктуру залізниць - слід залишити у власності держави або держава має володіти контрольним пакетом іiі акцій. Перевезення вантажів та пасажирів у далекому та приміському сполученні доцільно здійснювати на конкурентній основі. Експлуатаційні компаніїоператори за користування інфраструктурою повинні сплачувати компанії інфраструктури орендну плату або купувати нитку графіка.

4. Перед тим як організувати державні пасажирські експлуатаційні компанії-оператори, потрібно розробити систему антикризових заходів для зниження витрат на пасажирські перевезення, підвищення їх рентабельності за рахунок збільшення доходів від розширення транспортних та інших послуг.

5. 3 метою забезпечення керованості залізничним транспортом реформування структури його управління слід виконувати поетапно, поступово та послідовно готуючи зміни у діяльності нових юридичних осіб чи їх підрозділів. 


\section{СПИСОК ЛІТЕРАТУРИ}

1. Бараш Ю. С. Управління залізничним транспортом країни: Монографія. -2-ге вид. переробл. і допов. - Д.: Вид-во Дніпропетр нац. ун-ту залізн. трансп. ім. акад. В. Лазаряна, 2006. $264 \mathrm{c}$.

2. Бараш Ю. С. Види нових організаційних структур 3 управління залізничним транспортом в Україні та основні принципи їх побудови // Залізничний трансп. України. - 2006. - № 5, - С. 49-53.

3. Булгакова Ю. В. Концептуальный подход к реформированию ремонтной базы для грузовых вагонов в современных рыночных условиях / Ю. С. Бараш, Ю. В. Булгакова // Наук. вісн. Нац. гірничого ун-ту. - Д. : Вид-во НГУ, 2013. - № 3. - C. 126-133.

$\begin{array}{lll}\text { 4. Гудкова } & \text { В. П. Методологія }\end{array}$ забезпечення ефективної діяльності підприємств сфери пасажироперевезень: Монографія / В. П. Гудкова. - К.: ДЕТУТ, 2013. - 290 с.

5. Дикань В. Л. Удосконалення організаційної структури залізничного комплексу України в сучасних умовах / В. Л.Дикань, М. I. Данько, М. В. Кондратюк // Монограія. Харків: УкрДАЗТ, 2010. - 190 с.

6. Естіваль Ж.-П. Організаційні моделі залізниці: національні критерії побудови // Залізничний трансп. України. - 2005. - № 1. - С. 68-71.

7. Ейтутіс Г.Д. Стратегія реформування залізниць України на основі регіоналізації транспортного обслуговування: [Дисертація на здобуття наукового ступеня доктора економічних наук], Київ, 2010p.
8. Петренко Е.А. Реформирование железнодорожного транспорта Украины: теория, проблемы, пути решения: моногр./ Е.А.Петренко; НАН Украины, Ин-т экономики пром-сти. Донецк, 2011. - 358 с.

9. Петренко Е.А. Состояние и перспективы развития железнодорожного транспорта Украины в условиях проводимой реформы / Е.А. Петренко// Бюллетень ОСЖД. Варшава. - 2009. - № 4-5 (306-307) - С. 23-29.

10.Петренко Е. Ролята на дьржавата в дейността и реформирането на жп транспорта / Е. Петренко// Железопьтен транспорт (Railway transport magazine). - България, София. - 2010. №1. - C. $40-41$.

11.Пшінько О. М. Управління вантажними вагонами компаній-операторів в умовах реформування залізничного транспорту / О. М.Пшінько, Ю. С. Бараш, Л. В. Марценюк // Монографія / Дніпропетр. нац. ун-т. залізн. трансп. ім.. акад.. В. Лазаря на. - Дніпропетровськ, 2015. $147 \mathrm{c}$.

12.Чаркіна Т. Ю. Принципи формування інфраструктурної складової для побудови пасажирських залізничних тарифів / Т. Ю. Чаркіна // Зб. наук. праць Дніпропетр. нац. ун-ту залізн. трансп. ім. акад. В. Лазаряна. «Проблеми економіки транспорту». - Д.: Вид-во Дніпропетр. нац. ун-ту залізн. транспорт. ім. акад. В. Лазаряна, 2015. - Вип. 10. - С. 59-64

13.Юхновський I. P. Транспортний комплекс України. Залізничний транспорт: Проблеми та перспективи. За ред. I. Р. Юхновського. - К.: ФАДА ЛТД, 2006. - 288 с.

14.Gudkova V. P. Diagnostics of competitive ability by retroactive effect method / V. P. Gudkova // Nauka I Studia. - NR 2 (72). - 2013. - P. 31-36.

Експерт редакційної колегії к.е.н., дочент УкрДУЗТ Слагін Ю.В.

УДК 338.47:656.2

\title{
УДОСКОНАЛЕННЯ МЕТОДИКИ ОЦІНКИ ЕФЕКТИВНОСТІ ЕКСПЛУАТАЦЇ̈ ЛОКОМОТИВНОГО ПАРКУ ПАТ «УКРЗАЛІЗНИЦЯ»
}

\author{
Зіць О.Є., аспірант (ДЕТУТ)
}

На основі матричного підходу у статті здійснено порівняльний аналіз ефективності використання локомотивів за 2013 та 2014 роки.

3 метою усунення подвійного обліку або виключення впливу якісних показників на ефективність використання локомотивів визначені 4 вертикальних ієрархічних рівня, а також 